Int. J. Dev. Biol. 52: 3-7 (2008)

doi: $10.1387 /$ ijdb.072394ss

\title{
Peter Holland, homeobox genes and the developmental basis of animal diversity
}

\author{
SEBASTIAN M. SHIMELD* \\ Department of Zoology, University of Oxford, Oxford, U.K.
}

\begin{abstract}
In 1867 Alexander Kowalevsky published an account of the development of the cephalochordate Amphioxus lanceolatus (now known as Branchiostoma lanceolatum) (Kowalevsky, 1867). Together with his study of the development of urochordates (Kowalevsky, 1866; 1871), this introduced a new way of thinking about the relationship between the evolution and development of animals and established the basis for long-standing theories of the evolutionary origin of vertebrates. Some one hundred and fifty years later, cephalochordates and urochordates are again in the spotlight, as molecular biology and genome sequencing promise further revelations about the origin of vertebrates. The work of the 2006 Kowalevsky Medal winner, Peter Holland has played a central role in their reinstatement. Here, I profile Peter Holland's contribution to the rebirth of Evolutionary Developmental Biology in general and the study of homeobox genes and vertebrate origins in particular.
\end{abstract}

KEY WORDS: Peter Holland, homeobox, hox, amphioxus, evolution, gene duplication

\section{The 2006 Kowalevsky Medal Prize winner}

Professor Peter Holland, who for nearly 20 years has argued that the evolution of animal diversity can be understood by considering both the phylogenetic distribution of homeobox and other developmentally important genes and their association with genetic diversity and morphological variability, has won the 2006 Alexander Kowalevsky Medal, the International Prize for outstanding contributions to "Evo-Devo" research (for more details of the history of the Prize, see Mikhailov and Gilbert, 2000). He is the first UK researcher to win the Kowalevky Medal (Fig. 1).

Animal diversity, non-laboratory animal models (amphioxus and sea squirts to name but two), homeobox genes, comparative genomics, evo-devo: a few years ago these terms would have seemed to have as little in common as a zoologist and a molecular geneticist. And yet, according to Peter Holland, the Linacre Professor of Zoology and Associate Head of Oxford's Department of Zoology, they are united by similar goals: to understand the principles of animal diversity and evolution and how development fits into both. Peter has been a leading participant in all these developments.

Peter, an author of more than 120 papers including original scientific reports, reviews and essays and who has lectured extensively, is currently a Head of the Evolution and Development Research Group at the University of Oxford. The principle focus of the Group is the interplay between genes, embryos and evolution, through which the evolution of the homeobox gene superclass is a consistent and long-running theme. Currently, he and his colleagues are working on homeobox and other developmentally important genes in humans, rodents, fish, hagfish, amphioxus, ascidians, polychaetes, myxozoans, placozoans and choanozoans.

Rather than attempt to summarize these professional accounts of Peter's career, I revisit some of Peter's findings in relation to modern research in evo-devo and evolutionary biology. Achievements in amphioxus genetics and pure comparative genomics are mentioned when they impact on the central theme: homeobox genes and animal diversity.

\section{Homeobox gene diversity}

A little over twenty three years ago, Peter Holland graduated from Oxford University with a degree in Zoology and began studying for his $\mathrm{PhD}$ under the supervision of Brigid Hogan at the National Institute for Medical Research in London. This was an exciting time in Developmental Genetics. In the same year the homeobox had been identified through comparison of Drosophila homeotic genes (McGinnis et al., 1984b; Scott and Weiner, 1984) and it had recently become apparent that genes containing homeoboxes were also present in the genomes of other animals, including mice (Carrasco et al., 1984; McGinnis et al., 1984a).

\footnotetext{
*Address correspondence to: Dr. Sebastian Shimeld. Department of Zoology, University of Oxford, South Parks Road, Oxford, OX1 3PS, UK. Fax: +44 (0)1865-310-447. e-mail: sebastian.shimeld@zoo.ox.ac.uk
} 


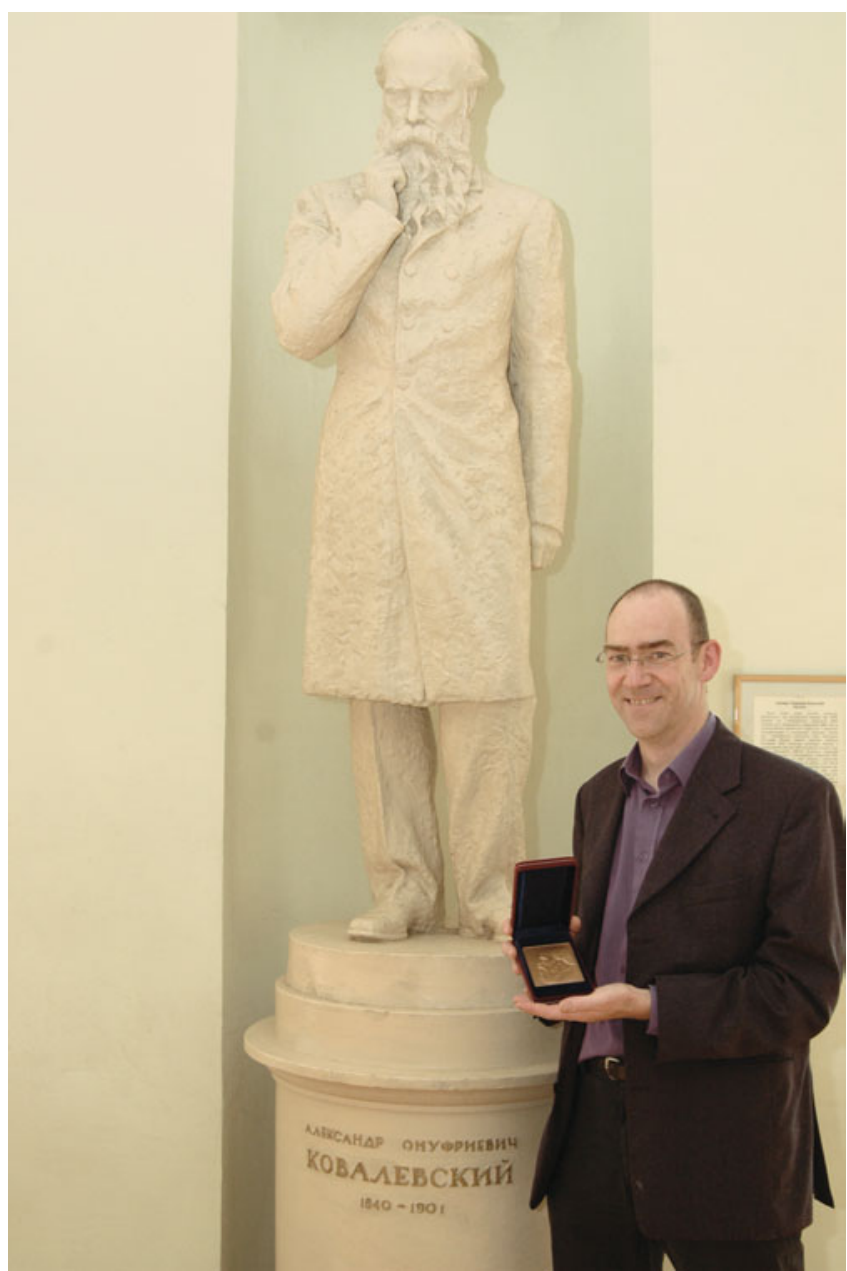

Fig.1. Peter Holland with the Kowalevsky Medal in 2007. The recipient is standing next to a statue of Alexander Kowalevsky situated in the Main Building of St. Petersburg University.

Peter began to study the expression of mouse homeobox genes during embryonic development (Holland and Hogan, 1988a; 1988b; Krumlauf et al., 1987) and as part of this he was instrumental in adapting to mice a technique previously used to study gene expression in Drosophila, that of in situhybridisation (Holland et al., 1987). Even at this early stage in his career, however, his evolutionary leanings were evident. In particular, he started to consider how widespread homeobox genes might be in the animal kingdom and began to address this question via Southern blots of DNA derived from a wide diversity of phyla, including echinoderms, molluscs, ribbon worms, brachiopods and flatworms (Holland and Hogan, 1986). The results of these studies illustrated the wide phylogenetic distribution of homeobox genes and it is the evolution of this genetic diversity and associated morphological diversity that has been a central focus of Peter's research over the following two decades.

\section{Gene duplication and chordate evolution}

In 1987 Peter moved to the Department of Zoology at Oxford, where he took on the role of Departmental Demonstrator and began to build his own research group. The Polymerase Chain Reaction (PCR) technique had just been developed and Peter set about exploiting it to examine two fundamental questions. The first was the phylogenetic relationships of the animal phyla. Understanding such phylogenetic relationships is pivotal to evolutionary biology and molecular data provided an additional source of information to morphology for phylogeny building. Using PCR, Max Telford (then a graduate student in Peter's lab) amplified fragments of ribosomal RNA genes to help resolve such phylogenetic relationships. In particular, they focused on the chaetognaths, an enigmatic phylum of planktonic worms then considered to be deuterostomes and hence closely related to the chordates. Their results demonstrated these worms are in fact protostomes and hence only distantly related to the chordates, a finding more recently reconfirmed with much larger datasets (Telford and Holland, 1993; 1997; Matus et al., 2006). The phylogenetic relationships of animals has continued to interest Peter, with more recent studies focused on enigmatic and poorly studied taxa such as the Strepsiptera, Hemichordata and Choanoflagellates (Rokas et al., 1999; Furlong and Holland, 2002; Philippe et al., 2004).

The major thrust of Peter's research at this time, however, concerned the timing and role of gene duplication in chordate evolution. Comparison of Drosophila and vertebrate homeobox genes was beginning to suggest that, whereas Drosophila had single representatives of many homeobox gene families such as Msxand Engrailed, vertebrates typically had two or more copies. Some twenty years before this, Susumu Ohno had suggested that tetraploidisation had been instrumental in the diversification of vertebrates (Ohno, 1970). This theory predicted that, among other things, some vertebrates would possess more copies of genes in most gene families than invertebrates. Peter and his group first began to investigate this by using PCR to examine the diversity of key homeobox gene families in the genomes of various invertebrates (Holland and Williams, 1990; Holland, 1991). In particular, they began to focus on those invertebrate taxa most closely related to the vertebrates, namely the cephalochordates and the urochordates. As more gene families were examined, it became apparent that while vertebrates consistently had multiple members of each family, cephalochordates and urochordates only had one. This led Peter to propose that the origin of vertebrates coincided with extensive gene duplication and that two rounds of tetraploidy were the likely route to these extra genes (Holland et al., 1994). This hypothesis has fundamental implications for vertebrate evolution, not least when considering the human genome, as it implies our genome is descended from an ancestral polyploidy. Not only should our genome bear the traces of this in the form of extensive regions of paralogy, the theory also provides a lucid explanation for the redundancy between gene family members often encountered in mouse knockout studies (much to the frustration of the researchers concerned). Hotly debated for many years, this hypothesis has recently received confirmation from the comparison of vertebrate genomes with that of the ascidian Ciona intestinalis (Dehal and Boore, 2005) and now provides a central explanation for some of the global facets of genome organisation and gene numbers in vertebrates. During this time, Peter also began a more detailed analysis of the Hox genes in amphioxus, Branchiostoma floridae. In collaboration with Nicholas and Linda Holland of the Scripps Oceanographic Institute, who had also begun to take an interest in 
Development

Volume 116 (3) November 1992

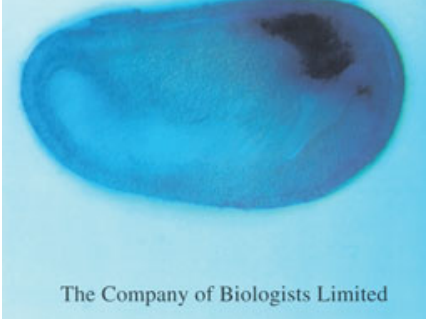

Fig. 2. Cover of the journal Development, depicting the first amphioxus in situ hybridisation. The expression of the Branchiostoma floridae AmphiHox3 gene is seen in the developing neural tube in a restricted anterior-posterior domain (For more information, see article by Holland et al., entitled "An amphioxus homeobox gene: sequence conservation, spatial expression during development and insights into vertebrate evolution". vol. 116 , pp. 653-661).

amphioxus development, a series of field trips to Tampa Bay, Florida commenced with the purpose of collecting amphioxus embryos for gene expression analyses. In 1992, they published the first in situ hybridisation study of an amphioxus Hox gene, demonstrating restricted expression along the anterior-posterior axis (Fig 2; Holland et al., 1992). In 1993 he was joined by Jordi Garcia-Fernandez, who began the marathon project of walking through the amphioxus Hox cluster by successive cloning of adjacent genomic phage clones. They completed and published the mapping of the anterior ten amphioxus Hox genes in 1994, a paper that remains heavily cited today (Garcia-Fernandez and Holland, 1994). This quintessential demonstration of a single, cohesive cluster of Hox genes provided crucial evidence for the ancient nature of Hox gene clustering and furnished a clear demonstration that the multiple Hox clusters identified in vertebrate genomes were a vertebrate innovation. This period also saw the start of expression studies of other amphioxus genes, initiating the establishment of a detailed molecular anatomy of amphioxus development and subsequent redefinition of homologies between amphioxus and vertebrates. Perhaps the most prominent example of this is the study of the amphioxus Otxhomologue, which helped redefine homologies between the vertebrate brain and amphioxus anterior central nervous system (Williams and Holland, 1988).

In the Spring of 1994 Peter, together with Michael Akam, Philip Ingham and Gregory Wray, organised the scientific programme of the annual meeting of the British Society for Developmental Biology on the theme of "Evolution of Developmental Mechanisms". This was a well attended and exciting meeting that to a large extent marked the return of Evolutionary Developmental Biology to the scientific mainstream in the United Kingdom. It resulted in a widely-read supplement to the Journal Development (Akam et al., 1994) and attracted many students and postdoctoral researchers into what became a rapidly growing field.

\section{Comparative genomics: amphioxus as a model}

In 1995 Peter was appointed Professor of Zoology at the University of Reading and set about extending his study of the evolution of the Hox gene clusters to other types of homeobox genes. In 1998, his laboratory reported the identification of the ParaHox gene cluster in amphioxus (Brooke et al., 1998). This enigmatic gene cluster is a sister to the Hox cluster, having split from an ancestral 'ProtoHox' cluster by duplication early in animal evolution, before the expansion of the Hox cluster in the bilaterians (Fig. 3A).

Mapping of amphioxus and human Nkx homeobox genes also confirmed an ancient origin for Nkx gene clustering (Luke et al., 2003). These data were further elaborated as the progress of the human and other genome projects allowed the pan-genomic mapping of vertebrate homeobox genes. The analysis of these genes proved to be profoundly insightful. Most homeobox genes can be broadly categorised into two large classes, the Antennapedia (or ANTP-) class genes (which includes the Hox, ParaHox, Nkx and others) and the paired (or PRD-) class genes. While the PRD-class genes appear to be distributed through the genome, the majority of ANTP-class genes can be traced to a single genomic region in a distant ancestor of the vertebrates. Peter and his colleagues referred to this as the 'Mega-homeobox' cluster (Fig. 3B; Pollard and Holland, 2000) and its identification indicates that most ANTP-class homeobox genes originally evolved by tandem duplication from a single ancestral ANTP-class gene. This has implications for the origin and genomic organisation of homeobox genes in all animal phyla. Typifying Peter's ability to adapt molecular techniques for evolutionary purposes, he went on to test this hypothesis by applying fluorescent in situhybridisation of chromosomes to amphioxus, an approach now widely used in the evolutionary genomics of non-model organisms (Castro and Holland, 2003).

\section{Oxford again: homeobox gene diversity, divergence and dispersal}

In October 2002, Peter returned to the University of Oxford as the Linacre Professor of Zoology, a post previously held by (amongst others) E.R. Lankester and E.S. Goodrich, both of whom made notable contributions to our understanding of vertebrate evolution through the study of amphioxus (see for example Lankester, 1889; Goodrich, 1930). Long-running research themes such as gene duplication and divergence, genome duplication and homeobox genes have remained a focus over recent years and the ever-expanding list of sequenced animal genomes has provided a rich source of information ripe for exploitation. The completion of the human genome project has allowed identification and classification of essentially all human homeobox genes and Peter and his lab have been instrumental in this process (Booth and Holland, 2004, 2007). Similarly, the completion of several vertebrate genomes, including those of three species of ray-finned fish, has allowed more complex questions of duplication, dispersal and divergence to be examined in detail. Most rayfinned fish appear to have descended from a tetraploid ancestor, the result of an extra genome duplication to those that occurred early in vertebrate evolution. Mapping the consequences of such extra duplications shows how genome duplication can break up ancient gene clusters, illustrating some of the forces involved in shaping the genome architecture of living species (Mulley et al., 2006).

\section{A central theme: homeobox genes and animal diversity}

Peter has remained an active teacher and mentor throughout his career. He currently contributes to all three years of Under- 


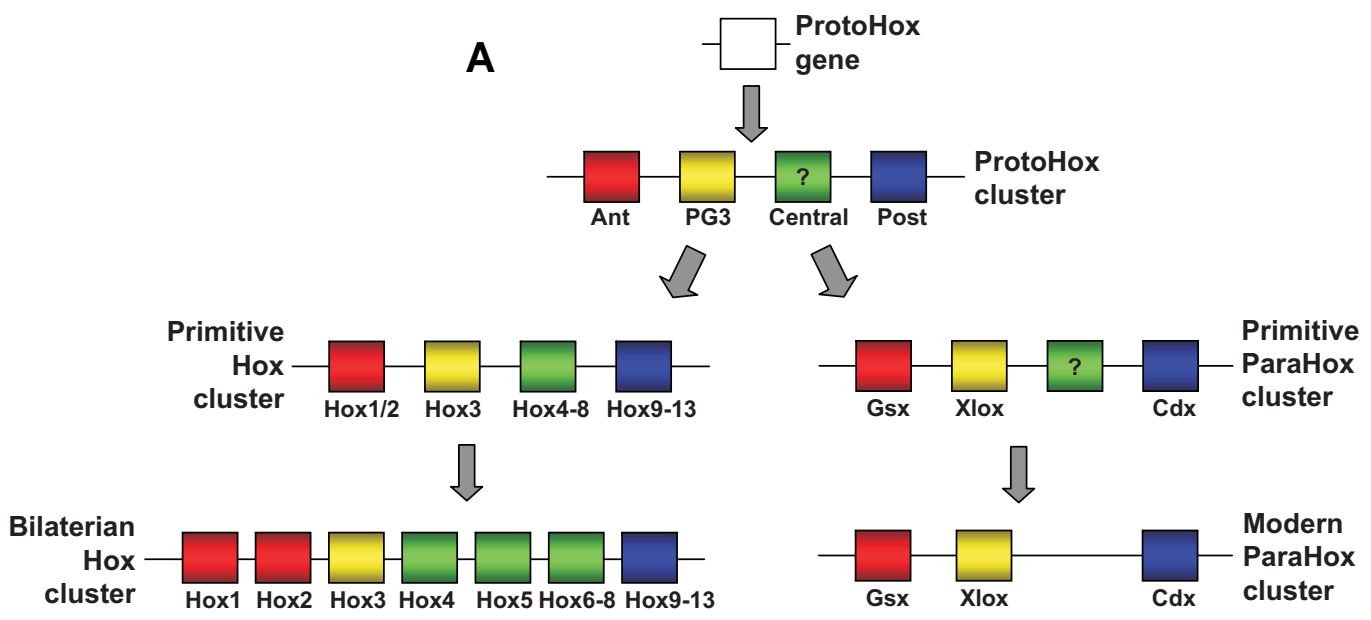

Fig. 3. Models of homeobox cluster gene evolution in the Metazoa. (A) A model for the evolution of the Hox and ParaHox gene clusters, based on that proposed by (Brooke et al., 1998). A single ProtoHox gene is proposed to have duplicated in tandem to yield a four gene ProtoHox cluster. This cluster then duplicated to yield the primitive Hox and ParaHox clusters. Further modifications have involved the loss of the paralogue group 3 (PG3) gene from the ParaHox cluster or the origin of the central Hox from within the Hox cluster and continued expansion by further tandem duplication of the Hox cluster (Ferrier and Holland, 2001). Variations of this basic model are also consistent with the data, for example see GarciaFernàndez (2005). (B) An expansion of the model shown in (A) that includes the additional ANTP-class homeobox genes proposed to be ancestrally related to the Hox genes as part of the Mega homeobox cluster (Pollard and Holland, 2000). A single ProtoHox gene duplicated in tandem to yield ancestors of the EHGbox cluster, Hox/ParaHox clusters and Nkx cluster. Further tandem duplications are inferred to have formed each cluster and the ParaHox and Hox clusters are inferred to have separated by an additional duplication. The compositions of the EHGbox cluster and Nkx cluster are shown below. Note precise gene order and complement in different species may vary.

graduate teaching on the Biological Sciences degree at the University of Oxford. Of the numerous students, postdocs and research fellows who have worked in his lab at one time or another, many are now running their own groups in the field of Evolutionary Developmental Biology, including in no particular order Jordi Garcia-Fernàndez, Max Telford, Hiroshi Wada, Martin Cohn, David Ferrier, Tokiharu Takahashi and the author.

Throughout Peter's research career, central themes have been the study of homeobox genes and the desire to understand the evolutionary origins of animal diversity, with a particular affection for the chordates. At its heart this reflects a genuine passion for zoology, with an appreciation for the subject's history and the imagination to integrate old questions and new ideas with the incisive potential of new techniques. Most recently, Peter has played a central role in the amphioxus genome project. Undertaken by the Joint Genome Institute and with an early assembly recently released for public access (http://genome.jgi-psf.org/ Brafl1/Brafl1.home.html), this advance promises to bring am- phioxus biology fully into the genomic era. I suspect Alexander Kowalevsky would have approved of the re-insertion of amphioxus and sea squirts into the scientific mainstream and it is perhaps fitting that the 2006 Kowalevsky Medal should be awarded to a scientist who has spent many years focused on those organisms that first brought Kowalevsky himself to international prominence.

\section{Acknowledgements}

I would like to thank members of my laboratory, Dr. David Ferrier and Dr. Alexander Mikhailov for comments on the manuscript and Professor Archil Dondua for Figure 1. Work in my laboratory is supported by the $B B S R C$ and the Royal Society.

\section{References}

AKAM, M., HOLLAND, P. W., INGHAM, P. AND WRAY, G. (1994). The Evolution of Developmental Mechanisms. In Development Supplement, (ed. Cambridge: The Company of Biologists Ltd. 
BOOTH, H. A. AND HOLLAND, P. W. (2004). Eleven daughters of NANOG. Genomics 84: 229-238.

BOOTH, H. A. AND HOLLAND, P. W. (2007). Annotation, nomenclature and evolution of four novel homeobox genes expressed in the human germ line. Gene 387: 7-14.

BROOKE, N. M., GARCIA-FERNÀNDEZ, J. AND HOLLAND, P. W. (1998). The ParaHox gene cluster is an evolutionary sister of the Hox gene cluster. Nature 392: 920-922.

CARRASCO, A. E., MCGINNIS, W., GEHRING, W. J. AND DEROBERTIS, E. M. (1984). Cloning of a X. laevis gene expressed during early embryogenesis coding for a peptide region homologous to Drosophila homeotic genes. Ce//37: 409-414.

CASTRO, L. F. AND HOLLAND, P. W. (2003). Chromosomal mapping of ANTP class homeobox genes in amphioxus: piecing together ancestral genomes. Evol Dev 5: 459-465.

DEHAL, P. AND BOORE, J. L. (2005). Two rounds of whole genome duplication in the ancestral vertebrate. PLOS Bio/3: e314.

FERRIER, D. E. AND HOLLAND, P. W. (2001). Ancient origin of the Hox gene cluster. Nat Rev Genet 2: 33-38.

FURLONG, R. F. AND HOLLAND, P. W. (2002). Bayesian phylogenetic analysis supports monophyly of ambulacraria and of cyclostomes. Zoolog Sci19, 5939.

GARCIA-FERNÀNDEZ, J. (2005). Hox, ParaHox, ProtoHox: facts and guesses. Heredity 94: 145-152.

GARCIA-FERNÀNDEZ, J. AND HOLLAND, P. W. (1994). Archetypal organization of the amphioxus Hox gene cluster. Nature 370: 563-566.

GOODRICH, E. S. (1930). The development of the Club-shaped Gland in amphioxus. Q J Microsc Sci. 74: 155-164.

HOLLAND, P. W. (1991). Cloning and evolutionary analysis of msh-like homeobox genes from mouse, zebrafish and ascidian. Gene 98: 253-257.

HOLLAND, P. W., GARCIA-FERNANDEZ, J., WILLIAMS, N. A. AND SIDOW, A. (1994). Gene duplications and the origins of vertebrate development. Dev Suppl, 125-133.

HOLLAND, P. W., HARPER, S. J., MCVEY, J. H. AND HOGAN, B. L. (1987). In vivo expression of mRNA for the Ca++-binding protein SPARC (osteonectin) revealed by in situ hybridization. J Ce/l Bio/105: 473-482.

HOLLAND, P. W. AND HOGAN, B. L. (1988a). Expression of homeo box genes during mouse development: a review. Genes Dev2: 773-782.

HOLLAND, P. W. AND HOGAN, B. L. (1988b). Spatially restricted patterns of expression of the homeobox-containing gene Hox 2.1. during mouse embryogenesis. Development 102: 159-174.

HOLLAND, P. W., HOLLAND, L. Z., WILLIAMS, N. A. AND HOLLAND, N. D. (1992). AN amphioxus homeobox gene: sequence conservation, spatial expression during development and insights into vertebrate evolution. Development 116 : 653-661.

HOLLAND, P. W. AND WILLIAMS, N. A. (1990). Conservation of engrailed-like homeobox sequences during vertebrate evolution. FEBS Lett 277, 250-252.

HOLLAND, P. W. H. AND HOGAN, B. L. (1986). Phylogenetic distribution of Antennapedia-like homeoboxes. Nature 321: 251-253.

KOWALEVSKY, A. (1866). Entwicklungsgeschichte der einfachen Ascidien. Mem
l'Acad St. Petersbourg, Ser 710: 1-19.

KOWALEVSKY, A. O. (1867). Die entwickelungsgeschichte des Amphioxus lanceolatus. Mem Acad St petersburg 11: 1-17.

KOWALEVSKY, A. O. (1871). Weitere studien uber die entwicklung der einfachen Ascidien. Arch Micr Anat 7: 101-130.

KRUMLAUF, R., HOLLAND, P. W., MCVEY, J. H. AND HOGAN, B. L. (1987). Developmental and spatial patterns of expression of the mouse homeobox gene, Hox 2.1. Development 99: 603-617.

LANKESTER, E. R. (1889). Contributions to the knowledge of Amphioxus lanceolatus Yarrell. Q J Micros Sci29: 365-408.

LUKE, G. N., CASTRO, L. F., MCLAY, K., BIRD, C., COULSON, A. AND HOLLAND, P. W. (2003). Dispersal of NK homeobox gene clusters in amphioxus and humans. Proc Natl Acad Sci USA 100: 5292-5295.

MATUS, D. Q., COPLEY, R. R., DUNN, C. W., HEJNOL, A., ECCLESTON, H., HALANYCH, K. M., MARTINDALE, M. Q. AND TELFORD, M. J. (2006). Broad taxon and gene sampling indicate that chaetognaths are protostomes. Curr Biol 16: R575-576.

MCGINNIS, W., GARBER, R. L., WIRZ, J., KUROIWA, A. AND GEHRING, W. (1984a). A homologous protein-coding sequence in Drosophila homeotic genes and its conservation in other metazoans. Ce//37: 403-408.

MCGINNIS, W., LEVINE, M. S., HAFEN, E., KUROIWA, A. AND GEHRING, W. J. (1984b). A conserved DNA sequence in homeotic genes of the Drosophila Antennapedia and bithorax complexes. Nature 308: 428-433.

MIKHAILOV, A. T. AND GILBERT, S. F. (2002). From development to evolution: the re-establishment of the «Alexander Kowalevsky Medal». Int J Dev Bio/46: 693698.

MULLEY, J. F., CHIU, C. H. AND HOLLAND, P. W. (2006). Breakup of a homeobox cluster after genome duplication in teleosts. Proc Natl Acad Sci USA 103: 10369-10372.

OHNO, S. (1970). Evolution by Gene Duplication. New York: Springer-Verlag.

PHILIPPE, H., SNELL, E. A., BAPTESTE, E., LOPEZ, P., HOLLAND, P. W. AND CASANE, D. (2004). Phylogenomics of eukaryotes: impact of missing data on large alignments. Mol Biol Evol21: 1740-1752.

POLLARD, S. L. AND HOLLAND, P. W. (2000). Evidence for 14 homeobox gene clusters in human genome ancestry. Curr Bio/10: 1059-1062.

ROKAS, A., KATHIRITHAMBY, J. AND HOLLAND, P. W. (1999). Intron insertion as a phylogenetic character: the engrailed homeobox of Strepsiptera does not indicate affinity with Diptera. Insect Mol Bio/8: 527-530.

SCOTT, M. AND WEINER, A. J. (1984). Structural relationships among genes that control development: sequence homology between the Antennapedia, Ultrabithorax and fushi-tarazu loci of Drosophila. Proc Nat/ Acad Sci USA 81: 4115-4119.

TELFORD, M. J. AND HOLLAND, P. W. (1993). The phylogenetic affinities of the chaetognaths: a molecular analysis. Mol Biol Evol10: 660-676.

TELFORD, M. J. AND HOLLAND, P. W. (1997). Evolution of 28 S ribosomal DNA in chaetognaths: duplicate genes and molecular phylogeny. JMo/ Evo/44: 135144.

WILLIAMS, N. A. AND HOLLAND, P. W. H. (1988). Old head on young shoulders. Nature 383: 490. 


\section{Related, previously published Int. J. Dev. Biol. articles}

See See our Special Issue on Evolution and Development edited by Jaume Baguñà and Jordi García-Fernández http://www.ijdb.ehu.es/web/contents.php?vol=47\&issue=7-8

Evolutionary embryology resurrected in Japan with a new molecular basis: Nori Satoh and the history of ascidian studies originating in Kyoto during the 20th century Shigeru Kuratani, Hiroshi Wada, Rie Kusakabe And Kiyokazu Agata Int. J. Dev. Biol. (2006) 50: 451-454

Hox and ParaHox genes in Nemertodermatida, a basal bilaterian clade Eva Jiménez-Guri, Jordi Paps, Jordi García-Fernández and Emili Saló Int. J. Dev. Biol. (2006) 50: 675-679

Head-tail patterning of the vertebrate embryo: one, two or many unresolved problems?

Claudio D. Stern, Jeroen Charité, Jacqueline Deschamps, Denis Duboule, Anthony J. Durston, Marie Kmita, JeanFrançois Nicolas, Isabel Palmeirim, Jim C. Smith and Lewis Wolpert Int. J. Dev. Biol. (2006) 50: 3-15

Pulling forces acting on Hox gene clusters cause expression collinearity

Spyros Papageorgiou

Int. J. Dev. Biol. (2006) 50: 301-308

Putting evo-devo into focus. An interview with Scott F. Gilbert

Alexander T. Mikhailov

Int. J. Dev. Biol. (2005) 49: 9-16

From development to evolution: the re-establishment of the «Alexander Kowalevsky Medal».

Alexander T Mikhailov and Scott F Gilbert

Int. J. Dev. Biol. (2002) 46: 693-698 [Abstract] [FullText]

Embryonic development of heads, skeletons and amphioxus: Edwin S. Goodrich revisited.

P W Holland

Int. J. Dev. Biol. (2000) 44: 29-34

Estimation of Hox gene cluster number in lampreys.

2006 ISI **Impact Factor $=3.577^{\star *}$

A C Sharman and $P$ W Holland

Int. J. Dev. Biol. (1998) 42: 617-620

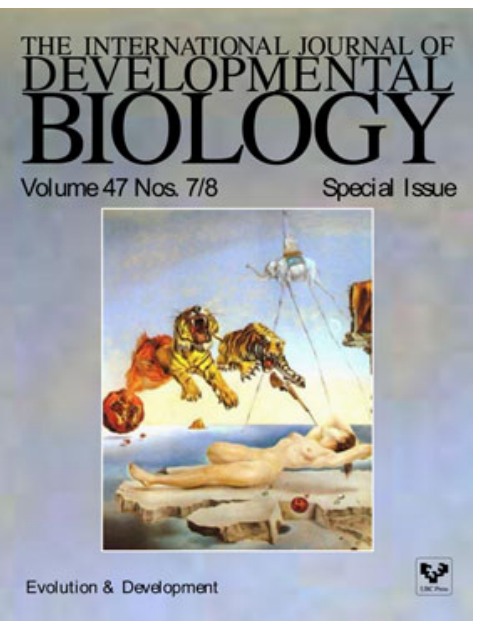

